\title{
Correction to: Fish composition, but not richness or abundance, differ among Phragmites, Typha, and Schoenoplectus zones during a high-water year
}

\author{
M. V. Croft-White (1) E. Budgell - C. Jacobs - S. E. Doka - D. T. Reddick • \\ J. Gardner Costa $\cdot$ J. D. Midwood
}

Published online: 25 October 2021

(C) Springer Nature Switzerland AG 2021

Correction to: Hydrobiologia

https://doi.org/10.1007/s10750-021-04687-7

The original article has been corrected. During production of this article, figure and table captions were mistakenly included in each reference to the figure or table in the text. These have been removed.

Publisher's Note Springer Nature remains neutral with regard to jurisdictional claims in published maps and institutional affiliations.

The original article can be found online at https://

doi.org/10.1007/s10750-021-04687-7.

M. V. Croft-White $(\bowtie) \cdot$ E. Budgell •

S. E. Doka · D. T. Reddick · J. Gardner Costa .

J. D. Midwood

Fisheries and Oceans Canada, Ontario and Prairie Region,

Great Lakes Laboratory for Fisheries and Aquatic

Sciences, 867 Lakeshore Road, Burlington,

ON, Canada

e-mail: Melanie.Croft-White@dfo-mpo.gc.ca

C. Jacobs

Walpole Island First Nation, 2185 River Road North,

Walpole Island, R.R. 3, Wallaceburg,

ON N8A 4K9, Canada 